\title{
An Investigation on the Entrepreneurial Factors that Influence the Performance of Coffee Marketing Co-Operatives in Nyeri County
}

\author{
Hesbon Kiura ${ }^{1}$, Paul Shavulimo ${ }^{2}$ \\ ${ }^{1,2}$ (Business Deparment, Kenya Methodist University, Kenya)
}

\begin{abstract}
Agriculture is the backbone of many African economies. Co-operatives as marketing vehicles deliver the commodities to the market in return to gain the desired remuneration on behalf of the farmers. Co-operatives are responsible for 45 per cent of the GDP and 31 per cent of national savings and deposits. Agricultural co-operatives' total turnover was $\$ 112$ million. They have 70 per cent of the coffee market, 76 per cent dairy, 90 per cent pyrethrum, and 95 per cent of cotton. The objective of the study was to determine the influence of entrepreneurial factors on the performance of coffee marketing cooperative societies in Nyeri County. The independent variables used in the research were marketing capabilities, environmental turbulence against the dependent variable of performance of coffee marketing societies. The study utilized descriptive survey. The target population was 23 coffee co-operatives in Nyeri County and the 23 general managers were the key informants in the study who responded to the questionnaires. The study revealed entrepreneurial factors such as marketing capabilities, environmental turbulence, and entrepreneurial orientation greatly influence the performance of coffee marketing co-operative society's profitability and growth in Nyeri County. The study recommends that all coffee marketing co-operative societies should strengthen entrepreneurial orientation capabilities and manage the coffee marketing environmental turbulence. The Nyeri co-operative County policy makers and planners should to put in place social-economic equity measures necessary to mitigate the declining global coffee prices that greatly influence the performance of coffee marketing co-operative societies to benefit the stakeholders in coffee industry as a whole. The research recommends further areas of factors retard their development is another important area for future research in coffee marketing co-operatives.
\end{abstract}

Keywords: Co-operative performance, Entreprenueral factors, Entrepreneurial orientation and Environmental turbulence

\section{Introduction}

This chapter gives the background of the study, statement of the problem, and the purpose of the study. Further, the general objectives and the specific objectives of the study are outlined. The research questions guiding the study are listed as well as the significance of the study. Finally, the assumptions of the research study are enumerated.

\subsection{Background of the Study}

Many countries that have achieved economic development have a vibrant and a dynamic cooperative sector which contributes substantially to the growth of those economies, (Satgar, 2008). 300 largest co-operatives had a combined annual turn-over of \$ 2 trillion in 2007.Further, Satgar and Williams (2008), Assert that the cooperative movement is one of the most organised social forces on the African continent. They cite the ILO which suggests that at least 7 percent of citizens in African countries belong to cooperatives, rising in countries like Mauritius, Egypt, Ghana, Kenya and Senegal to10 percent or more.

The cooperative movement in Africa plays a crucial role in economic and social transformation and in many parts of Africa it constitutes a parallel cooperative sector and economy as 40 per cent of African households belong to a cooperative (ICA 2012). Most successful cooperatives in the world have not evolved in isolation but as part of a cooperative movement (Satgar, 2008).

Following the liberalization in Kenya, co-operatives have witnessed major changes in the business environment that has seen the emerging of a competitive market economy. As a result their performance has been on the decline and subsequently members the loser, (GOK, 2010).

In agricultural sector, 30 per cent of cooperatives had failed to continue operating as the figures indicate 35 per cent of co-operatives were still registered could be dormant (Wanyama, 2009). The result was a stagnation of co-operatives as viable business organisations that cannot compete fairly and on equal footing with private businesses. Consequently, the collapse of cotton, dairy and coffee co-operatives lead to a sharp increase in levels of poverty in rural regions that depend on these crops. Some of the investments have ended up over burdening society members resulting to in ability to service member's financial requirements.

They have brought about business in efficiency and have become a net drain on internal resources, (GOK, 2012).Co-operatives are often blamed for non-performance mainly due to lack of participation on the part of their members. In agricultural cooperatives the entire business moves around the economic benefits which the members expect from their cooperative (Prakash, 2000). One of the central questions in the study of entrepreneurship is concerned with, is why new ventures succeed and others not (Cooper, Gascon, 1992).Many primary co-operatives risk running out of business due to weak internal control marketing capabilities unless they have adequately trained personnel to undertake modern marketing strategies and value addition initiatives. Cooperatives need adequate funding to enable them venture into new lines of investment and enhance their market share/capture. (GOK, 2012).Performance of the organisation is the yardstick by which the founder measures success (Chandler, Hanks, 1994). 
In Nyeri County, for instance, Nyeri co-operative union is the umbrella body for agricultural based marketing cooperatives. In year 2012, the union had accumulated losses realized from non performing activities such as manufacturing that had consumed 81 per cent of gross profit of the said activity (Audited accounts, 2012).However, there is need to investigate on the influence of entrepreneurial factors in the performance of coffee marketing co-operatives in Nyeri County.

\subsection{Statement of the Problem}

The dismal performance of the coffee sector in Kenya was attributed to a number of factors. These includes the collapse of 1989 international coffee agreement, global competition from countries like Vietnam and market glut. In addition local factors such as incomplete liberalization process, growing inefficiencies in cooperatives, and structural challenges in the coffee supply chain contributed to the decline in the coffee marketing performance (World Bank, 2006).

Nyeri County had 23 coffee marketing co-operative societies that earned Ksh 2.4 billion of which Ksh 1.41 billion was paid to members, which reflects an increase of 17 percent compared to year 2011 when ksh.1.17 billion was paid. Coffee marketing co-operatives were faced with numerous problems ranging from hawking of both cherry and mbuni coffee by co-operative members, theft of coffee parchment in factories, low production per unit of less than $3 \mathrm{kgs}$ per tree, farmers not getting farm inputs in good time, lack of access to cheap credit facilities by societies, lack of guaranteed coffee prices in world markets, chaos experienced from millers and coffee marketers to capture society's coffee and slow adoption of information communication technology (MOCD,2012). These problems reveal that, certain entrepreneurial factors have been influencing the performance of these market driven organisations and as such the co-operative entrepreneur needs to understand their business environment. However, no empirical studies have been done to reveal the extent to which these entrepreneurial factors influence the performance of those coffee marketing societies in Nyeri County. Therefore, this study is an investigation of those entrepreneurial factors influencing the performance of coffee marketing co-operative societies in Nyeri County.

\subsection{General Objective}

The general objective of this study is to determine the influence of entrepreneurial factors on the performance of coffee marketing cooperative societies.

\subsection{Specific Objectives}

(i) To determine the relationship between environmental turbulence and the performance of the coffee co-operative marketing cooperatives in Nyeri County.

(ii) To investigate the relationship of entrepreneurial orientation in influencing the performance of the coffee marketing cooperatives in Nyeri County.

\subsection{Significance of the Study}

The findings of this study will benefit the coffee marketing co-operatives in Nyeri County when making coffee marketing decisions in the midst of declining World coffee prices. The County policy makers and planners will use its findings to put in place social-economic equity measures necessary to mitigate the declining global coffee prices. The Kenya coffee industry will also use the findings of this study to plan for adequate coffee marketing capacity in for Co-operatives in the country. The findings will greatly influence the way co-operative societies manage their affairs to the benefit of the farmers that they are constituted to serve. The study will also spur entrepreneurial drive and inform businesses to invest in value addition in the coffee sub- sector. The study will be a wakeup call on the GOK to re-evaluate policy guidelines to create a more conducive policy framework for effective and efficient performance of coffee marketing co-operative societies in Kenya. The study will also be significant to the researcher to fulfill the requirements for the partial award of a degree in business administration, entrepreneurship option of the Kenya Methodist University.

\section{Literature Review}

\subsection{Introduction}

This chapter intends to look into the literature review, of the research study being undertaken and includes past studies done in the area of entrepreneurial factors influence to performance of coffee marketing cooperatives and issues that arise in performance of the societies and the theoretical framework. The researcher will also formulate a conceptual frame work.

\subsection{Theoretical Literature}

The word entrepreneur, can be traced back to the twelfth century, being rooted in the verb entreprendre, meaning to do something different (Long, 1983), and to its noun form entrepreneur, documented to be in use in as early as the fourteenth century (Hoselitz, 1960). The modern term entrepreneur evolved from the eighteenth century, first appearing in Savory's Dictionnaire Universal de Commerce (Paris, France, 1723), and subsequently used in the writings of Richard Cantillon (1680-1734), an eighteenth century financier and businessman. Entrepreneurship is generally accepted to be a contextual phenomenon, affected by the social, political, economic, and cultural environment in which it occurs. Beyond arguing for context utility, it has been posited that entrepreneurships dimensions may vary independently of each other in differing contexts (Stearns and Hills, 1996; Lumpkin and Dess, 1996).

Factors affecting business enterprises performance have been a well research area by scholars for many years. Previous research indicates that several factors influence business performance includes among many others: their professional background, their entrepreneurship capabilities and preferences, cultural and religious beliefs, as well as the 
technology and micro -environment (Buttner, 2001, Makhbul, 2011).Increasingly, entrepreneurship is being explored as a multi-dimensional concept combining previously separate conceptualizations into a broader construct. Both the individual and organizational elements are recognized to be context based (Lumpkin and Dess, 1996; Shanthakumar, 1992), and as a result of interaction with their environments, are posited to affect the formation and the performance of new ventures (Solymossy, 1998).Recent theoretical research in marketing has supported this idea.

In general, market-driven firms have consistently been predicted to outperform their internally-focused competition (Bharadwaj 1993; Day, 1994; Hunt and Morgan, 1995). These predictions are largely based on the idea that market-driven organizations will develop knowledge, skills, resources, and ultimately capabilities, that are rare, heterogeneous, and difficult to imitate (Barney, 1991; Hunt and Morgan, 1995), and that these capabilities will enable market-driven organizations to achieve positions of sustainable competitive advantage, ultimately resulting in superior financial performance (Day, 1994; Day and Wensley, 1988; Hunt and Morgan, 1995). Furthermore, empirical evidence from the more narrow market orientation research supports a positive impact on performance (Jaworski and Kohli, 1993; Narver and Slater, 1990)

\subsubsection{Environmental Turbulence and Performance}

According to Calantone, Garcia, and Droge(2003), a turbulent environment is defined as one in which frequent and unpredictable market and/or technological changes within an industry accentuate risk and uncertainty .An inability to forecast accurately, even within contingencies, helps to define turbulence from a top management team perspective. Three environmental characteristics influence the link between market orientation and Performance; Competitive intensity; Technology turbulence and Market turbulence (Kohli, Jaorski1 990). Further, Vorhies, Harker, Rao (1999) add that marketing channel capabilities for market-driven firms will develop more effective channels of distribution capabilities than less market-driven firms. Kohli and Jaworski (1990), define technology as the entire process of transforming input to output and delivery of those outputs to the end user. Technological turbulence may be interpreted as the frequency of changes in the entire industry's technology. They argue that the greater the technological turbulence, the weaker the relationship between a market orientation and a business performance. Chakravarthy (1997) asserts that, technological innovations may cause environmental turbulence by accelerating the rate of change both in scientific communities and in the market place. A firm may enjoy only temporary competitive advantage as product obsolescence occurs more quickly. This may also cause competitors to frequently enter and exit the market as they gain and lose profitable competitive advantage. Market turbulence refers to changes in the composition of customers and their preferences (Chakravarthy, 1997).

According to Jaworski and Kohli (1993), the greater the market turbulence, the stronger the market orientation/ business performance relationship. They further assert that, in a relatively stable market, with a fixed set of customers whose preferences are stable, a high level of market orientation is likely to have little adjustments to marketing mix elements is needed. Organizations that operate in more turbulent markets are most likely to modify their products and service continually in order to capture customers changing preferences. Jaworski, Kohli (1993) stated "Businesses operating in the more turbulent markets are likely to have a greater need to be market oriented (i.e. to track and respond to evolving customer preferences) compared to businesses in stable markets". Market turbulence is characterized by continuous changes in customer's preferences/demands, in price/cost structures, and in the composition of competitors. It also can be earmarked by the dissolution of traditional industry boundaries; this has occurred in the communications and media industries (Mullins and Sutherland, 1998). Marketplace disruptions can be based on real product innovation or just on expectations, waiting for a preannounced innovation effectively as a real product launch (Calantone, Garcia, and Droge, 2003).Sustainable competitive advantage lies in a firm's ability to quickly adapt to the changing environment (Calantone, Garcia, and Droge, 2003).

In Competition Intensity, Kohli and Jaworski (1990), attest that the greater the competition, the stronger the relationship between market orientation and business performance. In the absence of competition an organization may perform well even if it is not market oriented because customers do not have alternative options to satisfy their needs and wants so they have to accept the organizations offering of products or services. On the other hand, with a high degree of competition, customers have many alternative options to satisfy then desires (Houston, 1986, Kohli and Jaworski, 1990). In a situation of strong competition an organization that is not very market oriented is likely to lose customers to competitors. An organization that is very market oriented and focusing on its customers by understanding their needs and wants and responding to them is most likely to attract new customers or at least retain its current customers (Zairi, Duggan, 2013).

Channel capabilities differ greatly across industries. Firms, such as direct mail companies that sell direct to the consumer would be expected to develop relatively few channel capabilities. In contrast, firms with channel intermediaries between the firm and the end users of its products would need better developed channel capabilities (Vorhies, Harker, Rao, 1999). However, among firms with similar channels, market- driven firms would be expected to develop better relationships with channel members than other firms (Day, 1993, 1994). This is because market-driven firms will use their channels of distribution as a means to support their focus on end-user needs (Day, 1994). As a result, market-driven firms will develop better ways of servicing and supporting channel members than their competition, since the distributors and retailers who sell to the end-user often control important variables such as delivery times and shelf space. In addition, market-driven firms will strive for efficiencies in the channel whenever possible to hold down the likelihood of passing unnecessary costs on to the end-user (Vorhies, Harker, Rao 1999).As the environment becomes more turbulent, marketers must take more responsibility for introducing greater levels of entrepreneurship into all aspects of the firm marketing efforts. Marketing efforts have to become more customized and unique, with more customer choice in the form of a variety of value packages for different market segments (Despande, 1999). 


\subsubsection{Entrepreneurial Orientation and Performance}

Entrepreneurial orientation refers to the processes, practices, and decision-making styles of organizations that act entrepreneurially (Lumpkin, Dess, 1996).Keh, (2007), reports entrepreneurial orientation is a key concept when executives are crafting strategies in the hopes of doing something new and exploiting opportunities that other organizations cannot exploit. Ketchen, Short, (1998), clarifies the entrepreneurial orientation construct and linking it to performance. Any organization's level of entrepreneurial orientation can be understood by examining how it stacks up relative dimensions: autonomy; competitive aggressiveness; innovativeness; and risk taking.

Competitive aggressiveness is the tendency to intensely and directly challenge competitors rather than trying to avoid them. Aggressive moves can include price-cutting and increasing spending on marketing, quality, and production capacity. Although an aggressive move helps, too much aggressiveness can undermine an organization's success. A small firm that attacks larger rivals, for example, may find itself on the losing end of a price war. Establishing a reputation for competitive aggressiveness can damage a firm's chances of being invited to join collaborative efforts such as joint ventures and alliances. In some industries, such as the biotech industry, collaboration is vital because no single firm has the knowledge and resources needed to develop and deliver new products. Executives thus must be wary of taking competitive actions that destroy opportunities for future collaborating (Ketchen, Short, 1998).

Innovativeness is the tendency to pursue creativity and experimentation. Some innovations build on existing skills to create incremental improvements, while more radical innovations require brand-new skills and may make existing skills obsolete. Either way, innovativeness is aimed at developing new products, services, and processes. Those organizations that are successful in their innovation efforts tend to enjoy stronger performance than those that do not (Ketchen \& Short, 1998).

Risk taking refers to the tendency to engage in bold rather than cautious actions. Although a common belief about entrepreneurs is that they are chronic risk takers, research suggests that entrepreneurs do not perceive their actions as risky, and most take action only after using planning and forecasting to reduce uncertainty (Simon, Houghton, Aquino, 2000). Steps can be taken by executives to develop a stronger entrepreneurial orientation throughout an organization and by individuals to become more entrepreneurial themselves. For executives, it is important to design organizational systems and policies to reflect the four dimensions of entrepreneurial orientation. (Ketchen, Short, 1998).

Autonomy refers to whether an individual or team of individuals within an organization has the freedom to develop an entrepreneurial idea and then see it through to completion. In an organization that offers high autonomy, people are offered the independence required to bring a new idea to fruition, unfettered by the shackles of corporate bureaucracy. When individuals and teams are unhindered by organizational traditions and norms, they are able to more effectively investigate and champion new ideas some large organizations promote autonomy by empowering a division to make its own decisions, set its own objectives, and manage its own budgets. In some cases, an autonomous unit eventually becomes completely distinct from the parent company (Ketchen, Short, 1998).

\subsection{Organisational Performance}

Organizational performance is a multidimensional construct, tapping financial, operational, and customer-related performance domains (Kaplan and Norton, 1996; Venkatraman and Ramanujam, 1986). Growth (Kaplan and Norton, 1996; Venkatraman, 1989) reflects performance trends in terms of sales and market share gains. Growth in sales and market share are important to a business to ensure long term viability and resource availability (Kaplan and Norton, 1996; Varadarajan, 1983). Profitability reflects an efficiency view of current performance (Venkatraman, 1989). Profitability is viewed by some (Hunt and Morgan, 1995) as the ultimate organizational outcome and is commonly used in strategic marketing studies. Customer satisfaction (Day, 1990; Day and Wensley, 1988; Kaplan and Norton, 1992, 1993, 1996) represents the effectiveness of the organization in delivering value to its customers, while adaptability represents the ability of the firm to respond to changes in its environment (Ruekert, 1985). Adaptability is ultimately reflected in the market success of an organization's new products and/or services (Kaplan and Norton, 1996) represents the effectiveness of the organization in delivering value to its customers, while adaptability represents the ability of the firm to respond to changes in its environment (Ruekert, 1985).

Growth is a critically important factor to all firms (Varadarajan, 1983). Firms that cannot achieve and sustain growth in sales and market share eventually find themselves at a competitive disadvantage (Aaker and Day, 1986). As outlined by Day (1990), the sources of long term growth are: customer needs to be satisfied; technologies; customer segments served; geographic scope; and the firm's location in the value chain. Two of these factors, customer needs and segments served, are readily identified by the market- driven firm (Day, 1994). Interestingly, the firm with the most opportunities needs the most strategic discipline in order to be successful (Day, 1990). Thus, it is very important that firms not only develop market-orientation, but focus these processes through a strategic direction if growth is to be attained and sustained in the long term.

A strategically-focused market-driven firm would be well positioned to do this (Vorhie, Harker, Rao 1999).Many leading researchers have discussed the financial performance advantages believed to accrue to market-driven firms (Bharadwajetal., 1993; Day, 1994; Hunt and Morgan, 1995). To achieve superior profitability, market-driven firms will focus the processes and capabilities resulting from their market orientation on strategically important opportunities and problems (Day, 1994). As Hunt and Morgan (1995) state, "knowing its customers and competitors should allow the firm to respond to changes in consumer preferences and competitor strategies in an informed, perhaps even optimal manner". It is this set of capabilities that lie at the heart of the firm's ability to build and sustain the competitive advantage that serves as the basis for sustained profitability (Hunt and Morgan, 1995).In addition to adapting more skillfully to market needs, market-driven firms focus much of their strategic and tactical activities on delivering value to customers (Day, 1990, 1994). By providing customers with the right level of performance at the right price, market-driven firms do not require customers to spend money on benefits they do not want. 
Furthermore, satisfied customers typically demonstrate high levels of brand loyalty (Aaker, 1994) resulting in a reduction in the expenses necessary to retain these customers (Reichheld and Sasser, 1990). This means that market-driven firms must stay constantly focused on the needs of their targeted customers. However, market-driven firms have allimportant capabilities in market information gathering, market information processing, and responding to the needs of targeted customers (Kohli and Jaworski, 1990). When strategically focused on attractive market segments, these capabilities provide the means of achieving a sustainable competitive advantage (Bharadwaj et al., 1993). Given its central role in the market-driven firm, customer satisfaction is expected to be much higher in market-driven firms than in firms with more of an internal focus (Day and Wensley, 1988).However, the following two theories underpin the study.

\subsubsection{Economic Entrepreneurship Theories}

The economic entrepreneurship theory has deep roots in the classical and neo-classical theories of economics, and the Austrian market process (AMP).These theories explore the economic factors that enhance entrepreneurial behaviour. The classical theory extolled the virtues of free trade, specialization, and competition ,Ricardo, (1817); Smith, (1776).The theory was the result of Britain's industrial revolution which took place in the mid-1700 and lasted until the 1830s. The classical movement described the directing role of the entrepreneur in the context of production and distribution of goods in a competitive marketplace Say,(1803). Classical theorists articulated three modes of production: land; capital; and labour. There have been objections to the classical theory. These theorists failed to explain the dynamic upheaval generated by entrepreneurs of the industrial age, Murphy, Liao \& Welsch, (2006). Neo-classical Theory model emerged from the criticisms of the classical model and indicated that economic phenomena could be relegated to instances of pure exchange, reflect an optimal ratio, and transpire in an economic system that was basically closed. The economic system consisted of exchange participants, exchange occurrences, and the impact of results of the exchange on other market actors. The importance of exchange coupled with diminishing marginal utility created enough impetus for entrepreneurship in the neoclassical movement (Murphy, Liao \&Welsch, 2006). Some criticisms were raise against the neo-classical conjectures. The first is that aggregate demand ignores the uniqueness of individual-level entrepreneurial activity. Furthermore, neither use nor exchange value reflects the future value of innovation outcomes. Thirdly, rational resource allocation does not capture the complexity of market-based systems. The fourth point raised was that, efficiency-based performance does not subsume innovation and non-uniform outputs; known means/ends and perfect or semi-perfect knowledge does not describe uncertainty. In addition, perfect competition does not allow innovation and entrepreneurial activity. The fifth point is that, it is impossible to trace all inputs and outputs in a market system. Finally, entrepreneurial activity is destructive to the order of an economic system (Simpeh, 2011).

\subsubsection{Performance Theory}

Definitions of performance, institutions and governance, Performance is difficult to measure and interpret in the case of co-operatives, which generally aim to pay their members the best price for the products received, or to charge the lowest possible price for the inputs and services supplied (Dess \& Robinson, 1984; Kyriakopoulos ,2004). Several authors (Gassenheimer; Yavas., 1989; Miller, 1990; Clarke, 1991; Harrington 1991) define performance as improved product quality, productivity, technical efficiency, service capabilities of a firm, and logistical performance (which include an organisation's ability to meet promised delivery dates), and leading to sustainable profits. According to Dess and Robinson (1984), two popular measures of economic performance are return on assets and growth in sales. Cook and Plunkett (2006) points out that, for any form of a collective organization to achieve the highest performance, members` decisions about their own on-farm activities and investments should be aligned with the cooperative.

\subsection{Research Design}

\section{Research Methodology}

Research design is the plan, structure and strategy of investigation conceived so as to obtain answers to research questions. This study is a descriptive survey design which involves collection of quantifiable information from the sample and can also be used for describing and explaining the existing status of two or more variables at a given point in time and also for measuring characteristics of large populations (Mugenda and Mugenda, 1999).

A descriptive survey design is appropriate firstly because descriptions are informative. The method is useful in applied research in describing consumers attitudes (Fornell,1996).Secondly, descriptions are the starting points for identifying variables and building hypothetical, constraints that can be tested using other methods. Thirdly, description is sometimes the only way to study a behaviour or situation, because it is either physically or ethically impossible to produce it in an experiment. (Heiman, 1999).

\subsection{Target Population and Sampling Frame}

All items in any field of inquiry constitute a "universe" or "population" Kothari (2004).Mugenda (2003) while referring to Fisher, avers that in social sciences the following formula can be used to determine the sample size if the population is less than 10,000 .

$$
\left.n_{1} f=\mathbf{n} /(\mathbf{1}+\mathbf{n}) / N\right)
$$

Where: ${ }^{n} f=$ the desired sample size (when the target population is less than 10,000).

$\mathrm{n}=$ the desired sample size (when the population is more than 10,000)

$\mathrm{N}=$ the estimate of the population

The sample frame is a list, directory or index of cases from which a sample can be selected subjects or cases selected from the sampling frame form the units of observation in a study (Mugenda, 2003). A list of all 23 coffee marketing 
co-operative societies in Nyeri County is given on Appendix 4. In this study; the target population will be all the 23 registered coffee marketing co-operatives in Nyeri County (GOK, 2012). According to Mugenda (2003), when the target population is so small that selecting a sample would be meaningless, then taking the whole population in such cases is advisable.

\subsection{Data Analysis and Presentation}

Data will be analysed using both quantitive and content analysis of written materials from personal expressions of participants. The data collected from questionnaires, interviews and secondary sources will be summarized according to the study themes. Data will be analysed to determine its accuracy, credibility usefulness and consistency. According to Cooper and Schidler (2011), content analysis measures the semantic content or the "what" aspect of the message. Its breadth makes it flexible and wide ranging tool that is used as a methodology or as a problem specific technique. Quantitive data will be analyzed through after coding and inferences of responses will be used to give the results of the analysis which will then be presented in form of charts and tables and prose for qualitative data.

\subsection{Entrepreneurial orientation and performance}

\section{Data Analysis ,Interpretation and Presentation}

Any organization's level of entrepreneurial orientation can be understood by examining how it stacks up relative dimensions: autonomy; competitive aggressiveness; innovativeness; and risk taking.

\subsubsection{Competitive Aggressiveness}

Competitive aggressiveness is the tendency to intensely and directly challenge competitors rather than trying to avoid them. Competitive aggressiveness helps to increase society profits. The researcher measured the respondents beliefs using Likert scale and the results were summarized using the following table and presented in a pie chart.

Source: Author, (2014)

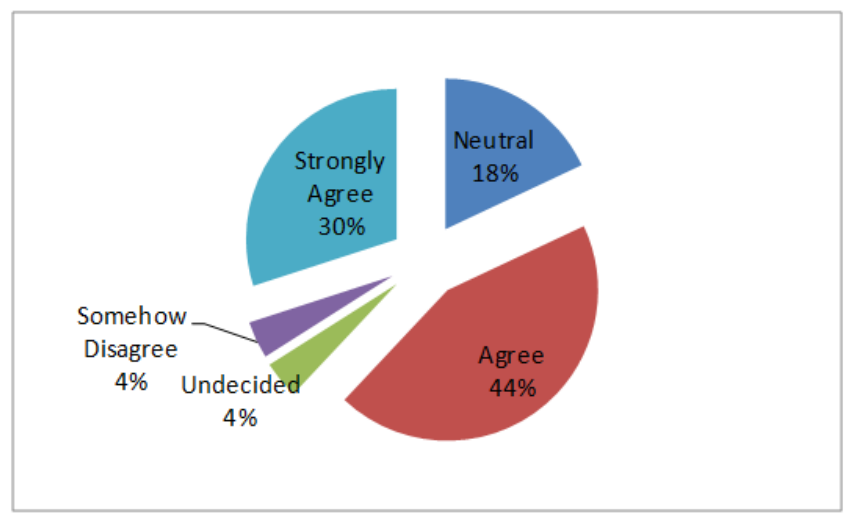

Figure 4.1: Competitive aggressiveness helps to increase society profits.

30 percent of the respondents strongly agree, while 44 percent agree that competitive aggressiveness helps to increase society profits. 18 percent are neutral while 4 percent somehow disagree and 4 percent are undecided. However, managers in the coffee marketing co-operatives feel that although an aggressive move helps, too much aggressiveness can undermine an organization's success as the study has revealed.

\subsubsection{Innovation Improves Products and Enhances Society Growth}

Innovativeness is the tendency to pursue creativity and experimentation. Innovation improves products and enhances society growth. Respondents expressed their feelings as measured using a Likert scale and summarized in the following table and presented in a pie chart.

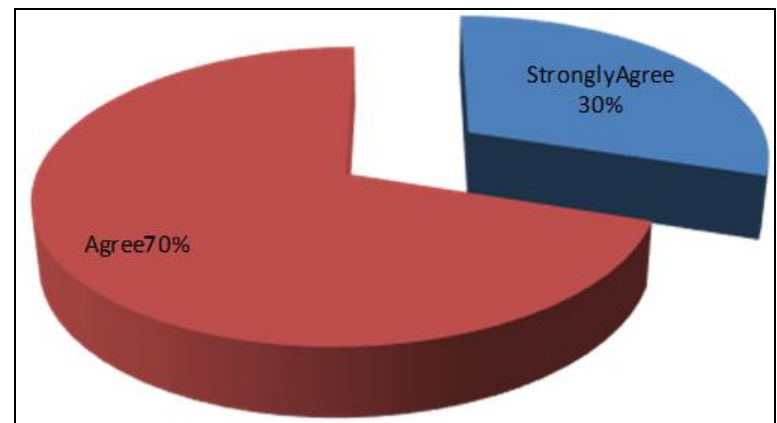

Source: Research data,(2014).

Figure 4.2: Innovation improves products and enhances society growth. 
30 per cent strongly agree and 70 percent agree that innovations improve products and enhance society growth. The study clearly shows that, managers of coffee marketing co-operative's require to be innovativeness aiming at developing new products, value addition of coffee ,improve services, and processes of these organizations. If they strategize to be successful in their innovation efforts they will tend to enjoy stronger performance in their co-operatives.

\subsubsection{Risk Bearing}

Risk taking refers to the tendency to engage in bold rather than cautious actions. Managing risk in the society enhances its growth. Through the questionnaires, the managers expressed their feelings measured using the Likert scale which were summarized using the following table and presented in a bar graph.

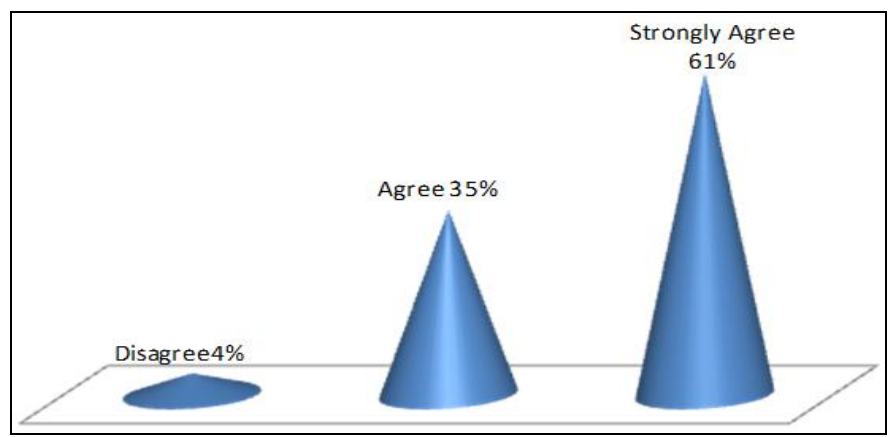

Source: Research data, (2014).

Figure 4.3: Managing risk in the Society Enhances its Growth.

61 percent strongly agree and 35 percent equally agree that managing risks in the society enhances its growth with only 4 percent disagreeing. Therefore, managers of coffee marketing co-operatives as entrepreneurs do not perceive their actions as risky, and most take action only after using planning and forecasting to reduce uncertainty and enhance society performance and its growth.

\subsubsection{Autonomy and independence}

Autonomy and independence in decision making increases profitability. The respondents expressed their feelings which were measured on a new scale and summarized on the following table and presented on a pie chart.

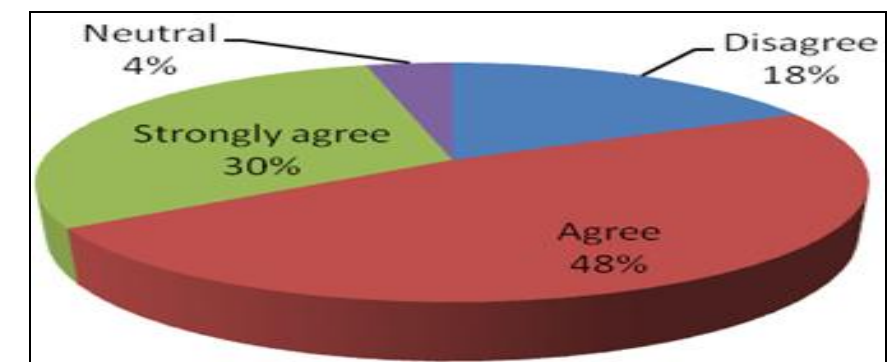

Figure 4.4: Autonomy and independence in decision making increases profitability.

Source: Research data, (2014).

30 per cent of the respondents strongly agree and 48 percent agree that autonomy and independence in decision making increases profitability. While 18 percent disagree with 4 percent remaining neutral. Coffee marketing co-operatives according to the research offers high autonomy, where managers are offered the independence required to bring a new idea to fruition, unfettered by the shackles of corporate bureaucracy hence enhancing the performance of these organisations.

\subsection{Environmental Turbulence and Performance}

A turbulent environment is the one which frequent and unpredictable market and/or technological changes within an industry accentuate risk and uncertainty. Four environmental characteristics influence the link between market orientation and Performance; Competitive intensity; Technology turbulence, Market turbulence and channel capabilities which this study focused on.

\subsubsection{Technological Turbulence}

Technological turbulence may be interpreted as the frequency of changes in the entire industry's technology. Technological disruptions reduce society adaptability to production. Respondent's feelings were measured using the Likert scale and summarized in the following table and then presented in a bar graph. 


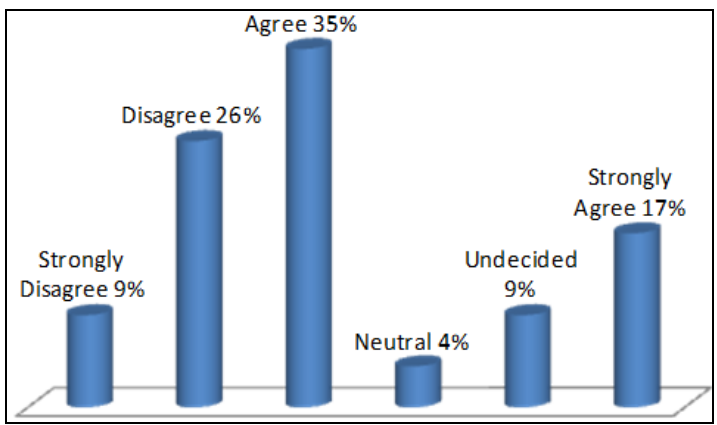

Table 4.5: Technological disruptions reduce society adaptability to production

Source: Research data, (2014).

17 percent of the respondents strongly agree and 35 percent agree that, technological disruptions reduce society adaptability to production. 9 percent strongly disagree, 26 percent disagree and 9 percent somehow disagree. The study shows that technological innovations may cause environmental turbulence by accelerating the rate of change both in scientific communities and in the market place for coffee marketing co-operatives. Mangers' inability to forecast accurately, even within contingencies, helps to define turbulence from a top management team perspective. Therefore, coffee marketing co-operative managers need to understand that the greater the technological turbulence, the weaker the relationship between a market orientation and a business performance of the co-operative.

\subsubsection{Market turbulence}

Market turbulence is characterized by continuous changes in customer's preferences/demands, in price/cost structures, and in the composition of competitors. A turbulent market destabilizes society growth. The respondent's beliefs were measured using new scale and summarized in the following table and presented in a bar graph.

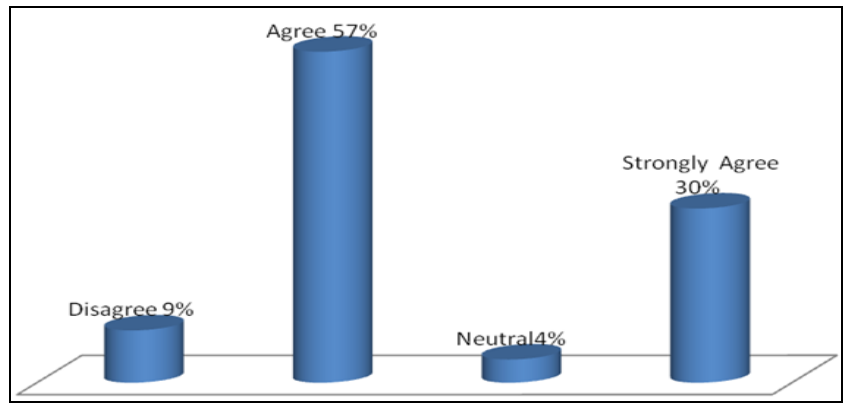

Figure 4.6: A turbulent market destabilizes society growth.

Source: Research data, (2014)

30 percent of the respondents strongly agree and $57 \%$ agree that market turbulence destabilizes society growth, whereas 9 percent disagree and 4 percent remained neutral. Since co-operatives as organizations that operate in more turbulent markets, they are most likely to modify their products and service continually in order to capture customers changing preferences. Therefore, managers need to understand that, the greater the market turbulence, the stronger the market orientation/ business performance relationship and coffee marketing co-operatives are likely to have a greater need to be market oriented as they operate in a turbulent market environment.

\subsubsection{Competitive intensity}

With a high degree of competition, customers have many alternative options to satisfy then desires. Competition enhances customer focus. The respondent's feelings were measured using the Likert scale and summarized using the following table and presented in a pie chart.

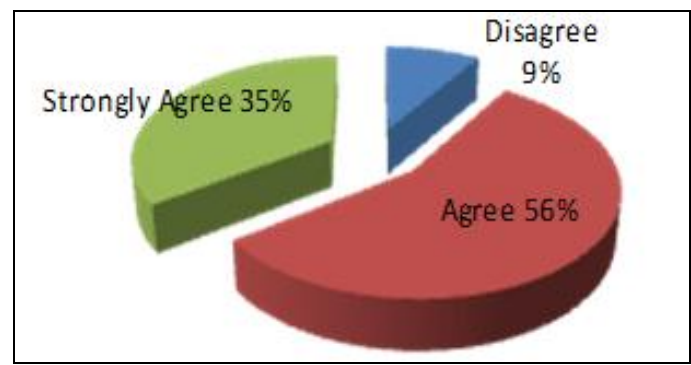

Figure 4.7: Competition enhances customer focus.

Source: Research data, (2014). 
35 percent of the respondent's strongly agree and 56 percent agree that competition enhances customer focus. Only 9 percent disagree. It is clear that managers of coffee marketing co-operatives understand that, an organization that is very market oriented and focusing on its customers by understanding their needs and wants and responding to them is most likely to attract new customers or at least retain its current customers. On the other hand, in a situation of strong competition an organization that is not very market oriented is likely to lose customers to competitors.

\subsubsection{Channel Capabilities}

Coffee marketing co-operatives as market-driven firms will use their channels of distribution as a means to support their focus on end-user needs. Efficient channel distributions enhance profitability in the society. During the study the respondents expressed their feelings measured in a Likert scale and summarized using the following table the results were presented in a bar graph.

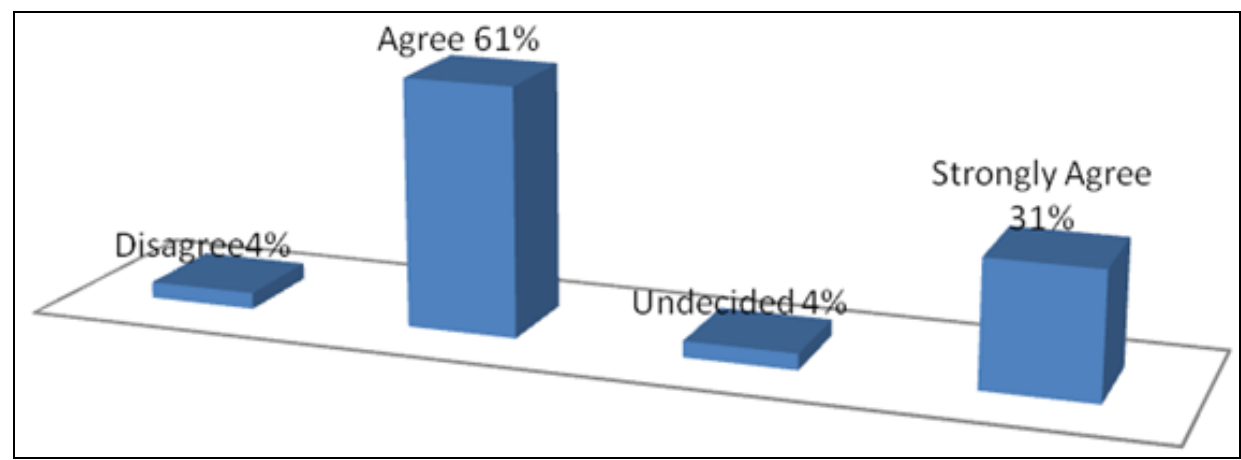

Figure 4.8 : Efficient channel distributions enhance profitability in the society

Source: Research data, (2014).

31 percent of the respondents strongly agree and 61 percent agree that an efficient channel distribution enhances profitability in the society. 4 percent disagree and 4 percent are undecided. This means that coffee marketing co-operatives as market-driven firms will strive for efficiencies in the channel whenever possible to hold down the likelihood of passing unnecessary costs on to the end-user. Thus, co-operatives as firms with similar distribution channels would be expected to develop better relationships with channel members than other firms in order to enhance coffee marketing channels and improve society profitability which is a key measure of society performance.

\subsection{Performance of Coffee Marketing Co-Operatives}

Organizational performance is a multidimensional construct, tapping financial, operational, and customer-related performance domains. Profitability, customer satisfaction, adaptability and growth experiences reflect the performance of the co-operative society investigated during the study.

\subsubsection{Profitability}

Profitability reflects an efficiency view of current performance viewed by some as the ultimate organizational outcome and is commonly used in strategic marketing studies. The society profitability is rising thereby increasing assets. Respondent's feelings were measured using a Likert scale and summarized using the following table and presented in a bar graph.

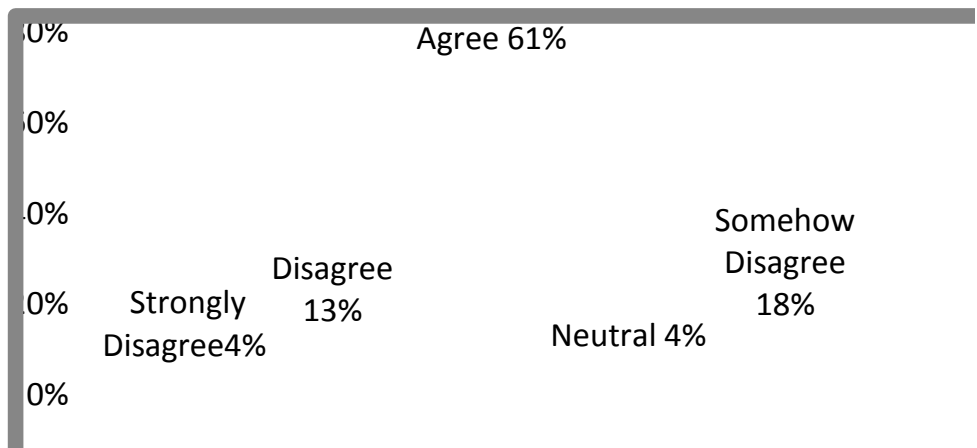

Source: Author, (2014).

Figure 4.9: The society Profitability is rising thereby increasing its Assets.

18 percent of the respondents strongly agree and 61 percent agree that profitability increases society assets. 4 percent strongly disagree while 13 percent disagree and 4 percent remained neutral. Profitability is viewed by managers as 
the ultimate organizational outcome. In coffee marketing co-operatives, profitability reflects an efficiency view of current performance as the society net worth will grow due to profitability of the society as the study has shown.

\subsubsection{Customer satisfaction}

Customer satisfaction represents the effectiveness of the organization in delivering value to its customers. The study investigated whether the society customers are satisfied with the performance of their society. The respondent's beliefs were measured using the Likert scale summarized in the following table and presented in a pie chart.

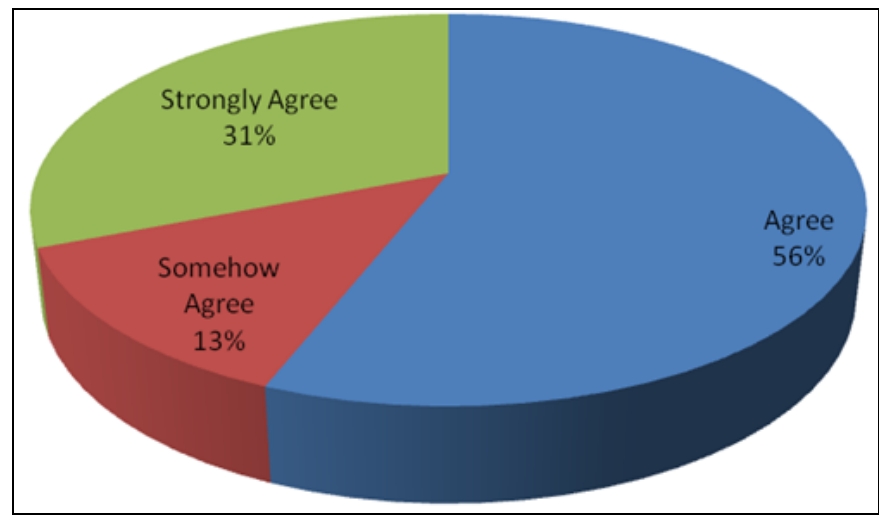

Figure 4.10: The society customers are satisfied with the performance of their society.

Source: Research data, (2014).

31 percent strongly agree, 56 percent agree that the society customers are satisfied with the performance of the coffee marketing co-operatives, where 13 percent somehow disagree. Managers in coffee marketing co-operative societies should focus knowing its customers and competitors to allow the co-operatives respond to changes in consumer preferences and competitor strategies in an informed, perhaps even optimal manner to enhance their performance and derive optimum satisfaction to customers.

\subsubsection{Growth}

Growth is a critically important factor to all firms. The society has been experiencing growth due to its performance. The respondents expressed their beliefs which were measured using the Likert scale and summarized in the following table and presented in a bar chart.

\begin{tabular}{|c|c|c|}
\hline & $\begin{array}{c}\text { Agree } \\
61 \%\end{array}$ & \\
\hline $\begin{array}{cc}\text { Strongly } & \\
\text { Disagree } & \text { Disagree } \\
4 \% & 4 \%\end{array}$ & & $\begin{array}{l}\text { Strongly } \\
\text { Agree 22\% } \\
\text { Neutral } \\
9 \%\end{array}$ \\
\hline
\end{tabular}

Figure 4.11: The society has been Experiencing Growth due to its Performance.

Source: Research data, (2014).

22 percent of the respondents strongly agree, 61 per cent agree that the society has been experiencing growth due to its performance. 4 percent strongly disagree, 4 per cent disagree and 9 per cent remain neutral. Coffee marketing cooperatives sources of long term growth are: customer needs to be satisfied; technologies; customer segments served; geographic scope; and the firm's location in the value chain. Market driven organisations that cannot achieve and sustain growth in sales and market share eventually find themselves at a competitive disadvantage. Therefore, to sustain the society's growth, managers should draw strategies aimed at achieving long term growth for the co-operatives.

\subsubsection{Adaptability}

Adaptability represents the ability of the firm to respond to changes in its environment. The society is able to adapt to changes due to its performance. Managers expressed their feelings which were measured using the Likert scale and summarized in the following table and presented in the following pie chart. 


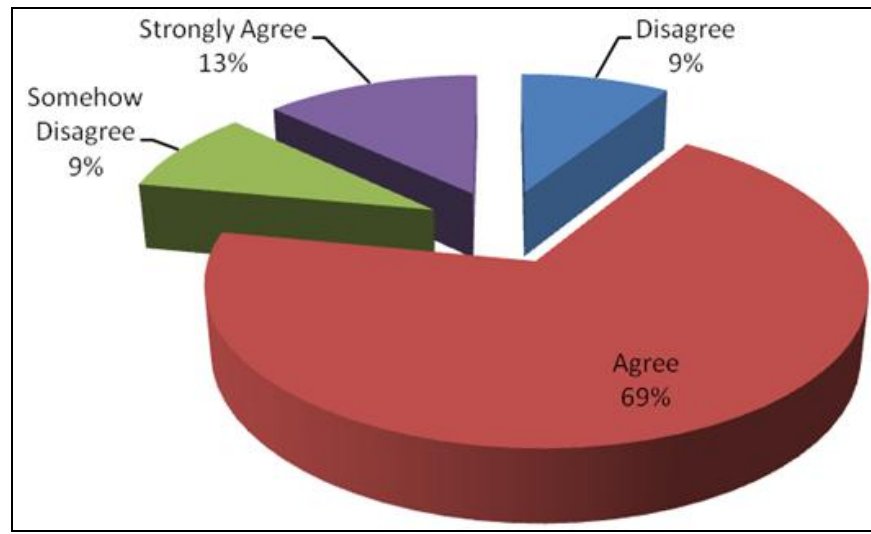

Figure 4.12: The Society is able to Adapt to Changes due to its Performance.

Source: Research data,(2014).

13 percent of the respondents strongly agree and 69 percent agree that, the society is able to adapt to changes due to its performance. 9 percent disagree and another 9 percent somehow disagree with this view. This means that while Coffee marketing co-operatives are market- driven firms may not be the most innovative firms in their industry (as measured by patents, etc.), they will excel at adapting technologies to meet customer needs. Thus, they may exhibit some of the adaptive characteristics of the analyzer organization. By developing market information and focusing it around strategic actions, these market-driven firms will be better at introducing new products to the market and will have larger numbers of successful new product than their competition. Managers should draw strategies focused on adaptability to changes to enhance society performance.

\subsubsection{General Rating of the Performance of the Coffee Marketing Co-Operatives}

Performance is difficult to measure and interpret in the case of co-operatives, which generally aim to pay their members the best price for the products received, or to charge the lowest possible price for the inputs and services supplied. To assess and evaluate the performance of their societies, mangers were given the opportunity to give an opinion of the society. To achieve this goal the researcher developed a table whose ratings were based on a new scale on the society's performance and summarized on the following table and presented using a pie chart.

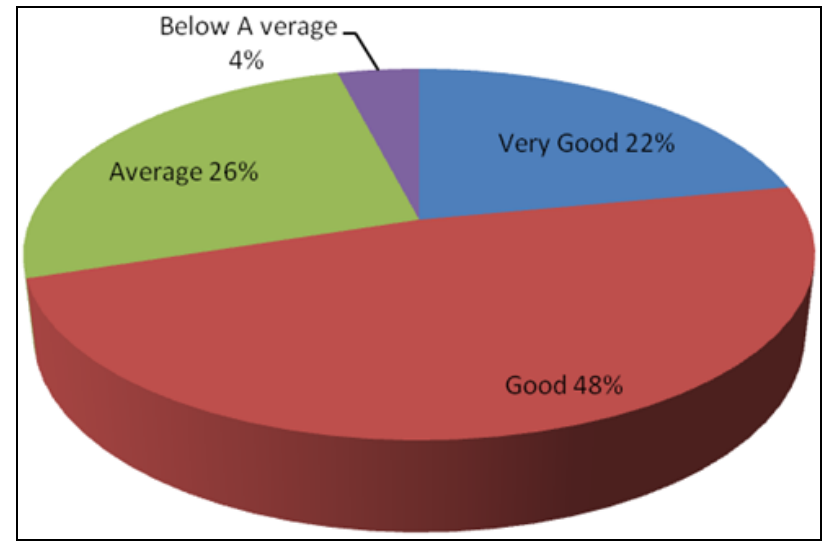

Figure 4.13: Rating of the Performance Coffee Marketing Co-operatives in Nyeri County.

Source: Research data, (2014).

The above figure shows the rating of the performance of the coffee marketing co-operatives tin Nyeri County. Out of 23 coffee marketing co-operatives, five of them constituting 22 percent were rated very well in terms of performance. Eleven societies constituting 48 percent were rated good. Six societies constituting 26 per cent were rated average. One society constituting 4 percent was rated below average.

\subsubsection{Explanations of the Performance Ratings.}

The researcher sought to find out the reasons for rating the society performance ranging from excellent to very poor. The explanations given by the managers are cited below in each category.

\subsubsection{Very good Performance}

The five best coffee marketing co-operative societies in this category in Nyeri County include: Barichu farmers, Gacatha farmers, Gakuyu farmers, Mugaga farmers, and New Gikaru farmers. Some of the reasons contributing to the very good performance include: good payments to farmers, good management, improved technology, good governance, the 
society's ability to meet its targets and the conducive working environment created between staff, members and management committee.

\subsubsection{Good Performance}

The eleven coffee marketing societies that were rated with good performance include: Gikanda farmers, Giakanja farmers, Iriaini farmers, Mutheka farmers, Mathira North farmers, Othaya farmers, Rugi farmers, Rutuma farmers, Rumukia farmers, Thiriku farmers and Tekangu farmers. The reasons given for this good performance include: increase in production of coffee, computerization, prompt debt payments, compliance to co-operative laws, reduced members complaints, growth in membership, increase in share capital, and increase in profitability and timely payments to members.

\subsubsection{Average Performance}

The six societies that had average performance ratings include: Aguthi farmers, Gathaithi farmers, Githiru farmers, Kiama farmers, Ruthaka farmers and Wachuri farmers. The reasons given by managers for average performance of these societies were: Unpredictable coffee prices and high prices of production, inadequate finance for operations and farm inputs, wrangles between members, low productivity, political interferences, low coffee prices, lack of value addition initiatives and uncontrolled coffee marketing forces.

\subsubsection{Below Average Performance}

One society that is Njuriga farmers was rated below average. The reasons given for this performance were mainly low production and lack of member's loyalty. Although the majority of coffee marketing societies according to the study are performing well, based on performance theory, they need to improve performance relating to improved product quality, productivity, technical efficiency, service capabilities of a firm, and logistical performance (which include an organisation's ability to meet promised delivery dates), and leading to sustainable profits. Those societies that are average and below average on performance, require drawing strategic plans aiming at improving their performance and service delivery to farmers.

\subsection{Suggestions on How to Improve Performance of Coffee Marketing Co-Operatives.}

The researcher sought to find solutions for improving the performance of coffee marketing co-operatives. Solution's suggested by managers include: forming farmers groups, encourage good agricultural farming practices, educate members, enhance coffee policies, encourage research and development, issue farmers with farm inputs timely, encourage good coffee payments, encourage coffee certification programmes, Government to reduce taxes on coffee, encourage coffee local consumption, elimination of coffee marketing cartels and middlemen, amendments of society by-laws, diversifications of productions, educating staff, members to improve quality and quantity production, improve internal control systems, improve coffee payments to members, improve quality and quantity, avail funds for value addition, allow autonomy and independence in decision making, enhance direct marketing, organize seminars and workshops, create a pool of funds that can be obtained cheaply by societies, embrace computerization of society activities, access to cheap credit facilities, encourage the youth to undertake coffee farming business, reduce expenses, build milling plant and promote value addition initiatives. According to this research, the solutions given if undertaken will help improve coffee marketing co-operatives in Nyeri County.

\subsection{Summary of the Study}

\section{Summary of Findings, Conclusions and Recommendations}

The objective of the study was to determine the influence of entrepreneurial factors on the performance of coffee marketing cooperative societies in Nyeri County. The specific research objectives were to determine the relationship between environmental turbulence and the performance of the coffee co-operative marketing cooperatives; to investigate the relationship of entrepreneurial orientation in influencing the performance of the coffee marketing co-operatives; to determine the influence of market orientation in the performance of coffee marketing cooperatives; and to evaluate the influence of marketing capabilities in the performance of coffee marketing co-operatives in Nyeri County. Data collected confirmed that entrepreneurial factors influence the performance of coffee marketing co-operatives.

This research project was designed to accomplish two main objectives. The first objective of this study was to establish the relationship of entrepreneurial orientation in influencing the performance of the coffee marketing co-operatives. The relationship of entrepreneurial orientation in influencing the performance of the coffee marketing co-operatives in the research was understood by establishing how entrepreneurial orientation referring to the processes, practices, and decisionmaking styles of organizations that acts entrepreneurially. As the results of this study demonstrated, the 23 coffee marketing co-operatives were influenced by adaptability, customer satisfaction, growth, and profitability dimensions. This finding supports the theoretical work in marketing regarding the capabilities of market-driven firms (Day, 1993, 1994; Day and Wensley, 1988) and extends the empirical findings of the market orientation researchers (e.g. Kohli and Jaworski, 1993; Narver and Slater, 1990) beyond simple measures of performance. Managers need to examine how these organisations stacks up the relative entrepreneurial dimensions: autonomy; competitive aggressiveness; innovativeness; and risk taking that enhance the performance of the society to increase profitability, and enhance the society growth.

The fourth objective was to determine the relationship between environmental turbulence and the performance of the coffee co-operative marketing cooperatives. The researcher established that environmental turbulence is characterized by competitive intensity; technological disruptions, market turbulence and channel capabilities greatly influence the performance of coffee marketing co-operatives. Most respondents acknowledged that competitive intensity in the coffee 
industry enhances customer focus as with high degree of competition, customers may have many alternative options to satisfy then desires hence affecting performance of society in terms of profitability. Technological disruptions were viewed as a major concern as that the greater the technological turbulence, the weaker the relationship between a market orientation and a business performance. The study established that coffee marketing co-operatives are characterized by market turbulence and most likely they need to modify their products and service continually in order to capture customers changing preferences. The societies need efficient channel distributions to enhance profitability, growth and performance.

\subsection{Conclusions.}

The study of the entrepreneurial factors influencing the performance of coffee marketing cooperative societies in Nyeri County was meticulously and specifically zeroed down on the following independent variables: market capabilities, market orientation, entrepreneurial orientation and environmental turbulence. The dependent variable was performance measured by society growth, profitability, customer satisfaction and society adaptability. Through a census of the 23 coffee marketing co-operatives in Nyeri County the main key informants who were mangers of these societies successfully filled the questionnaires hence a 100 percent success rate of the respondents.

The research findings established that entrepreneurial factors greatly influenced the performance of coffee marketing co-operatives as entrepreneurial orientation and environmental turbulence have a direct relationship in influencing the performance of coffee marketing co-operatives.

\subsection{Recommendations}

On entrepreneurial orientation, the researcher recommends that coffee societies need to innovate constantly by sourcing knowledge from their customers. Co-operatives should adopt appropriate competitive aggressive strategies aimed at increasing their market share that will result to raised revenue earnings for coffee farmers. The societies should also develop strategies to minimize risks as well as the effect of these risks in coffee business. Also management of societies should have more autonomy and independence and involve all people in decision making process so that they can feel and act in a positive manner that could lead to higher performance.

On environmental turbulence, the researcher established that, technological disruptions destabilize society production processes. The societies should adopt efficient and appropriate coffee technology to curb future losses that may arise from technological disruptions. The study established that a turbulent market destabilizes the society's growth in terms of share capital and membership. The society should employ appropriate coffee marketing strategies that will help in curbing coffee market instabilities. This could result in societies seeking for niche markets, promotion of local coffee consumption, promote value addition initiatives and promote more of coffee direct sales in the world coffee market. It is important that the channel distribution be efficient to enhance profitability to support the focus on end user's needs.

\section{References}

[1]. Calantone,R., Garcia, R., \& Droge C. (2003).The effects of Environmental Turbulence on New Product Development Strategy Planning, Product Development \& Management Association,Vol.2, pages 90-103.

[2]. Gray, T.W. \&Stevenson, G.W. (2008).Cooperative Structure for the Middle: Mobilizing for Power and Identity, Food and the MidLevel Farm: Renewing Agriculture of the Middle, edited by Lyson, pp. 37-53.

[3]. Chenney, G. (1995), Democracy in the work place. Theory and practice from the Perspective of Communication, Vol.23.pp.167-200.

[4]. Groove, F. (1985). What is cooperation? The philosophy of cooperation and its Relationship to Cooperative Structure and Operations: UWCC Occasional paper No. 6, Madison.

[5]. GOK (2012). Nyeri County Annual Report.

[6]. Hariyoga, H. (2004), An Economic Analysis of Factors Affecting the Failure of an Agricultural Marketing Cooperative: The Bankruptcy of Tri Valley Growers, A Dissertation submitted to the Office of Graduate Studies of Missouri in partial fulfillment for the Degree Doctor of Philosophy, pp. 3-24.

[7]. Harris, A.(2007).Agricultural Cooperatives:Astart-up guide. Retrieved from

[8]. http://www.agf.gov.bc.ca/busmgt/bus_arrange_pdf/coopl.pd.

[9]. Jaworski, B. J. \& Kohli, A. K.(1993). Market Orientation: Antecedents and Consequences,

[10]. Journal of Marketing, 57 (July), 53-70.

[11]. Kohli, A. K. \& Jaworski, B. J. (1990).Market Orientation: The Construct, Research Propositions, and Managerial Implications,Journal of Marketing, 54 (2), 1-18.

[12]. Kothari C. A. (2004). Research methodology: Methods and Techniques; 2nd revision edition; New age international publishers, New Delhi.

[13]. Kyriakopoulos,K.(1999).Market orientation of European Agricultural Cooperatives: strategic and structural issues:Paper presented to the IXth Congress of the European Association of Agricultural. Economists, "European Agriculture Facing the 21 Century in a Global Context" Retrieved from http://www.nyenrode/nl/nice rom.

[14]. Kibuka G, (2011). An examination of Factors influencing entrepreneurial intention of High school students in Kenya: (Unpublished Doctoral Dissertion, University of Illinois- Champaign). Retrieved from http://hdl.handle.net/2142/24351

[15]. Karubiu J. (2012). An investigation of the factors influencing Customers Retention in savings and credit cooperatives (Sacco's): A case study of Bingwa Sacco in Kirinyaga: Individual Research Report, Department of Business Administration,Kenya Methodist University. BPRP/14

[16]. Mokhtar, M.Z., Kamil N.F. \&Muda M.S. (2006).Evaluation of Factors Affecting Corporate Performance of Malaysian Listed Companies, International Journal of Economics and management 1(1), 91-116.

[17]. Karanja, A.M.; Nyoro, J.K. (2002): Coffee process and regulation and their impact on livelihoods of rural community in Kenya.Tegemeo Institute of Agricultural Policy and Development, Egerton University, Nairobi, Kenya.

[18]. Machethe. C.L. (1990). Factors contributing to poor performance of Agricultural cooperatives in less developed areas.Agekon.

[19]. Mugenda O. (2003), Research Methods, Quantitive \& qualitative1st Edition, Published by Act Press Publications. 
[20]. Narver, J., \& Slater, S. (1990). The effect of a market orientation on business profitability.

Journal of Marketing, 54(4), 2036.Narver, J., \& Slater, S. (1994). Market orientation, customer value and superior performance.Business Horizons, 2, $22-28$.

[21]. Narver, J. C. \& Slater, S. F. (1990).The Effect of Market Orientation on Business Profitability,

[22]. Journal of Marketing, 54 (October), 20-35.

[23]. NDCU, (2012), Audited accounts.

[24]. Ruoro M .(2012. An investigation into factors influencing performance of cooperative investments' survey of selected co-operatives in Nyandarua County.Individual Research Report, Department of Business Administration,Kenya Methodist University.BPRP/8.

[25]. Seliger Jawahir I.S, Kraisheh M.K (2011); Advances in sustainable Manufacturing: Proceedings of 8th Global conference on sustainable Manufacturing: Springer, New York.

[26]. Slater, S. F, and Narver, J.C, (1995), Market orientation and Learning organization: Journal of Marketing.

[27]. Simpeh N.K. (2011), Entrepreneurship theories and Empirical Research: A summary Review of the Literature; European Journal of Business Management, Ghana.

[28]. Tilahum D, D. (2012),Performance of coffee marketing cooperatives and Members satisfaction in Dale District; Southern Ethiopia.Unpublished thesis to be submitted to the school of Graduate Studies in partial fulfillment of the requirement for the Degree of Master of Science in Agriculture,Haramaya University; Haramaya.

[29]. Talammi, K.K. (1997), Cooperatives in the new Environment: A study of the role of Registrar of co-operative societies in selected countries in Asia, Rome.

[30]. Tchami, G.(2007)..Handbook on cooperatives for use by workers organisations; ILO, Geneva.

[31]. United States Department of Agriculture (2002), Agricultural Cooperatives in the 21st

[32]. Century, Rural Business-Cooperative Service, Cooperative Information Report 60, 1-9.

[33]. Venktraman, N, N. (1989). The concept of fit in strategy research: Toward Verbal and statistical correspondence:Academy of management Review.

[34]. Vorlaufer.M., Wollni.M.,\&Mithöfer.D.(2012),Determinants of collective marketing performance: Evidence from Kenya`s coffee cooperatives.Selected Paper prepared for presentation at the International Association of Agricultural Economists (IAAE) Triennial Conference, Foz do Iguaçu, Brazil.Retrieved from http://ageconsearch.umn.edu|bitstream|12660|vorlaufer|AAE.

[35]. Vorhies, W.A, Harker M. \& Rao C.P., (1999).The capabilities and performance advantages of market driven firms..Vol.33, Issue. $11 / 12$; pg. 1171

[36]. Wang,C.L.(2008).Entrepreneurial orientation, learning orientation, and firm performance. Entrepreneurship Theory and Practice, 32(4): 635-656

[37]. Wanyama, O.F.,(2009).Surviving Liberization: The cooperative movement in Kenya; (Coop Africa working Paper No.10). ILO,Geneva.

[38]. Zeulli, A.K, (2004), Cooperatives; Principles and Practices in the 21st century; Cooperative Publishing; Winsconsin. 